\title{
Risk Assessment of Industrial Fires for Surrounding Vulnerable Facilities Using a Multi-Criteria Decision Support Approach and GIS
}

\author{
Saadet Alkış ${ }^{1}$, Ercüment Aksoy ${ }^{2}$ and Kudret Akpınar 1,*(D) \\ 1 Department of Civil Defense and Fire Fighting, Akdeniz University, 07070 Antalya, Turkey; \\ salkis@akdeniz.edu.tr \\ 2 Department of Geographic Information Systems, Akdeniz University, 07070 Antalya, Turkey; \\ ercumentaksoy@akdeniz.edu.tr \\ * Correspondence: akudret@akdeniz.edu.tr; Tel.:+90-242-310-6741 or +90-505-588-1283
}

check for updates

Citation: Alkış, S.; Aksoy, E.; Akpınar, K. Risk Assessment of Industrial Fires for Surrounding Vulnerable Facilities Using a Multi-Criteria Decision Support Approach and GIS. Fire 2021, 4, 53. https://doi.org/10.3390/fire4030053

Academic Editor: Grant Williamson

Received: 6 July 2021

Accepted: 20 August 2021

Published: 25 August 2021

Publisher's Note: MDPI stays neutral with regard to jurisdictional claims in published maps and institutional affiliations.

Copyright: (c) 2021 by the authors. Licensee MDPI, Basel, Switzerland. This article is an open access article distributed under the terms and conditions of the Creative Commons Attribution (CC BY) license (https:/ / creativecommons.org/licenses/by/ $4.0 /)$.

\begin{abstract}
The fires encountered in the buildings and facilities of industrial areas make up quite a small proportion of all fire cases. However, in terms of the heat release rate, size of the burned area, damage, and impact zone, such fires have a large impact as compared to other fire cases. All fires have risk in terms of propagation. However, since fires in industrial structures and plants have rather high levels, qualitatively and quantitatively, compared to residential fires and other types of fires, it should be regarded as necessary to research them extensively. In this study, fires that have broken out in various places around Turkey, such as in factories, cold storage plants, and manufacturing facilities, were investigated. We aimed to determine the level of risk of the occurrence of these fires in the environment. A large amount of detailed information gathered about these fires was analyzed. This information includes data about the causes of the fires, deformation data of various materials, data on technical problems, data on financial damage levels, and data on fire patterns. We found 40 of these fire cases in total, and the case data were used to calculate the risk scores with the Geographic Information System (GIS), Analytical Hierarchy Process (AHP), and Inverse Distance Weight (IDW) methods. For each fire case, places sensitive to damage and losses were assessed according to six main criteria. Buffer analysis maps were generated for the 40 fire cases, and the cases were ordered based on their overall risk scores. In this ordering, fire case number 21 was found in the riskiest region, and fire cases 32, 17, and 31 were found in the low-risk region. Fire case number 21 occurred in a factory used for manufacturing fabric. This factory works with high volumes of acrylic, polyester, and other raw materials. In addition, there are some structures in very close proximity. It was observed that fire cases could be well differentiated depending on the selected criteria in the model applied.
\end{abstract}

Keywords: fire risk; analytical hierarchy process; inverse distance weight; industrial area fires; GIS

\section{Introduction}

Fires in industrial zones are known to make up a small percentage of all fire cases. According to the report published on the website of the Department of the Fire Brigade of İstanbul Metropolitan Municipality, which shows the data for all fire cases encountered during the last five years (up to the end of 2020) [1], 301,663 of all types of fire cases took place in İstanbul, and only 844 of them were factory fires, corresponding to a ratio of $2.8 \%$ of all cases. Such a ratio is rather low compared to the residential fire ratio of $22.1 \%$. It was realized that no study on nationwide statistics for industrial fires was available in Turkey. Thus, data about industrial fires had to be found individually from the websites of the Fire Brigade Departments of Municipalities. For instance, 72,922 fire cases were encountered during the last 6 years in İzmir province [2]. Of these cases, 389 (0.53\%) were factory and similar fire cases. This number was quite low compared to the number of 
residential fire cases $(18 \%)$. In a study about fire cases in three provinces (İstanbul, İzmir, and Sakarya; Sakarya had the greatest number of factory fire cases in 2018), 2971 fire events were reported in Sakarya, and of these cases $622(20.9 \%)$ were residential fires and 241 $(8.1 \%)$ were workplace, workshop, and factory fires [3]. These statistics included smallscale workplaces in residential areas. However, such places are not taken into account in the factory and large warehouse fire data recorded for İstanbul and İzmir. If it was not included here, the data from factory, warehouse, and workshop fires alone would show a value of less than $8.1 \%$. However, these data revealed that, despite the greatest ratio of factory fires occurring that year, the occurrence of factory and large warehouse fires is still relatively lower than that of residential fires.

Despite their fairly low proportion, fires in industrial buildings or facilities generate a large amount of heat and cause extensive material damage to buildings compared to residential fires. According to a survey report published by NFPA in 2018, 37,910 fires were encountered in industrial and production facilities in the USA between 2011 and 2015, and such fires generated a direct material damage of about 1.2 billion dollars annually [4]. This amount has been estimated to be $12.2 \%$ per year out of the entire losses caused by fires that occurred between the same years [5].

There are various sources of ignitions in factory and production facilities. Electricity systems, heaters, inattention, and negligence are basic factors that are similar to ignition sources in other places, but factory and production places have various other sources of ignition which are more likely to occur. The number of such fire cases is so high that it is impossible to include them all in a single report. Electricity is utilized in factories, production facilities, and attached warehouses, and there is a diverse range of electrically operated utensils. There are various electrically operated machines, conveyors, loaders/unloaders, heaters, mixers, coolers, and lighting utensils operating for long hours. There are also several continuously operating electrical devices or machines. Too many extension cables are used, and overloading and shorting wear-outs generate conditions favorable for the initiation of fires. Activity-generated static discharge also constitutes an important fire starter [6]. Some production activities are continuously ongoing in these facilities, and combustible dust generated during the production, storage, packaging, and transportation of raw materials and processed products may also constitute a considerable fire hazard in such places $[7,8]$. When these clouds of dust are not removed by a sufficient ventilation system, they may spread throughout the entire facility and then cause a fire. Melting, heating, soldering, hot-jointing, and similar techniques involving heat are serious fire hazards. Several other fire hazards not mentioned herein or dangers related to processes specific to production facilities are either not encountered at all or are far less common in residential areas. Despite their low proportion out of the total number of fires, it is highly significant to assess the risks caused by fires in factories, production places, and adjacent warehouses (such as cold storage areas) in the regions affected and the environment.

Risk assessments play an important role in fire research. Studies on the sensitivity of a region (geographically) to fire [9-13] or risk assessments for specific types of fires (for instance, open area fires, forest fires, residential fires) [14-18] have used multi-criteria decision-making (MCDM) methods, geographical information systems (GIS), mathematical models, and combinations of these methods.

Ji et al. (2018) considered the risks encountered in the production, transportation, and storage of flammable/explosive materials, which constitute the most dangerous elements of industrial zones [19]. Since there is a complex relationship between combustion and blast in these materials and analyses that do not take this issue into consideration will have a large amount of ambiguity, a mathematical model that included "the domino effect" generated by this relationship was proposed. The domino effect is known as an initial accident that may be encountered in storage facilities for flammable/inflammable/explosive materials, oil refineries, filling areas, and storage/distribution facilities and that may turn into a catastrophic accident through sequential fires, flashes, and explosions [20-22]. An accident or a fire encountered initially in an industrial area unit may result in an explosion 
(fire-explosion), and an initial explosion may then initiate a fire (explosion-fire), or a fire encountered in a unit may initiate fires in other units (fire-fire). Kadri et al. (2013) categorized the effects of fires and explosions under four headings: (I) overpressure/blast waves, (II) heat load, (III) projection of fragments, and (IV) toxic release [23]. In a study investigating 224 fire cases that took place in different facilities of the world due to the domino effect between the years of 1917 and 2009, the incidence of fires was reported to fall in these categories [24]. These cases included an LNG tank explosion in Cleveland, USA, in 1944. In that case, an initial leakage turned into a fire, and a series of explosions resulted in 128 deaths, 200-400 injuries, extensive property damage, and serious financial damage. Another case was the explosion of a vapor cloud in a butane storage facility in Montreal, Canada, in 1957. Following the explosion, a fire was initiated, three BLEVE explosions took place, and three storage units were seriously damaged. In 1975, chemical vapor accumulation and a series of fires were encountered in ethylene/propylene facilities in Beek, Holland, with the case resulting in 14 deaths, 104 injuries, and damage within a $4.5 \mathrm{~km}$-diameter area. The courses of all these fires or development patterns were as specified above. In other words, the first case occurred in the order fire-explosion, the second occurred in the order explosion-fire, and the third occurred in the order fire-fire.

In industrial areas, oil and chemical facilities are subject to risk assessments, since such facilities contain high quantities of flammable/inflammable materials, and these materials pose a great risk. However, there is always a risk of fire, even in factories, depots, and production facilities in which flammable/inflammable materials are not stored, or where the storage of these materials is not the main purpose. Moreover, since the perception of danger is low in facilities that are not related to oil and chemicals, the distance of such facilities from residential areas is usually shorter, and the safety measures taken at these facilities are relatively relaxed. Although two factors (I and IV) that can cause a domino effect in the types of accidents encountered in oil and chemical facilities do not have to be considered in places other than these facilities, the heat load (II) and projection of fragments (III) should be considered as factors influencing the environment in all factories, large production facilities, depots, and industrial areas. It is always possible that the heat released may reach high levels in fires in industrial areas if these fires find favorable conditions.

In this study, large factory fires and fire cases that have occurred in various warehouses and cold storage facilities in Turkey since 2010 were taken into consideration. The facilities and warehouses affected by these fires were not used for purposes relating to oil, fuel, mineral oil, or chemicals. The most significant factor with regard to the impacts of these fires on the environment is related to heat load and dissipation, as mentioned above. In the cases mentioned above, fires progressing at high temperatures were encountered. In such cases, the distance from the location where the fire started to surrounding areas that may be influenced is an important issue; thus, analyses were conducted accordingly.

Following the incidence of fires in various parts of Turkey, relevant fire cases are examined in situ with an official application to the Civil Defense and Firefighting Department of Vocational School of Technical Sciences in Akdeniz University. In light of the data gathered in these investigations, the potential risk these fires posed to the surrounding environment was assessed in this study.

\section{Materials and Methods}

\subsection{Research Site}

Turkey is located in the northern hemisphere in a place connecting the continents of Europe and Asia. The geographic location is between the $36^{\circ}$ and $42^{\circ}$ north parallels and the $26^{\circ}$ and $45^{\circ}$ east meridians. Turkey, which has a total surface area of $783,562 \mathrm{~km}^{2}$, is surrounded by the Mediterranean Sea, the Aegean Sea, and the Black Sea (Figure 1).

The majority of the information about the fire cases considered in this study was gathered from the reports prepared by the first author of this paper, who participated in in situ investigations of those fire cases as a Post-Fire Evidence Response Team expert. 
Full addresses and similar identifying information relating to these fire cases will not be presented because of the legal rights of the individuals and companies involved. Only information relating solely to the subject matter will be shared. The locations of these fire cases of interest are presented in Figure 2. The exact coordinates will also be kept confidential and will not be shared due to the reasons specified above.

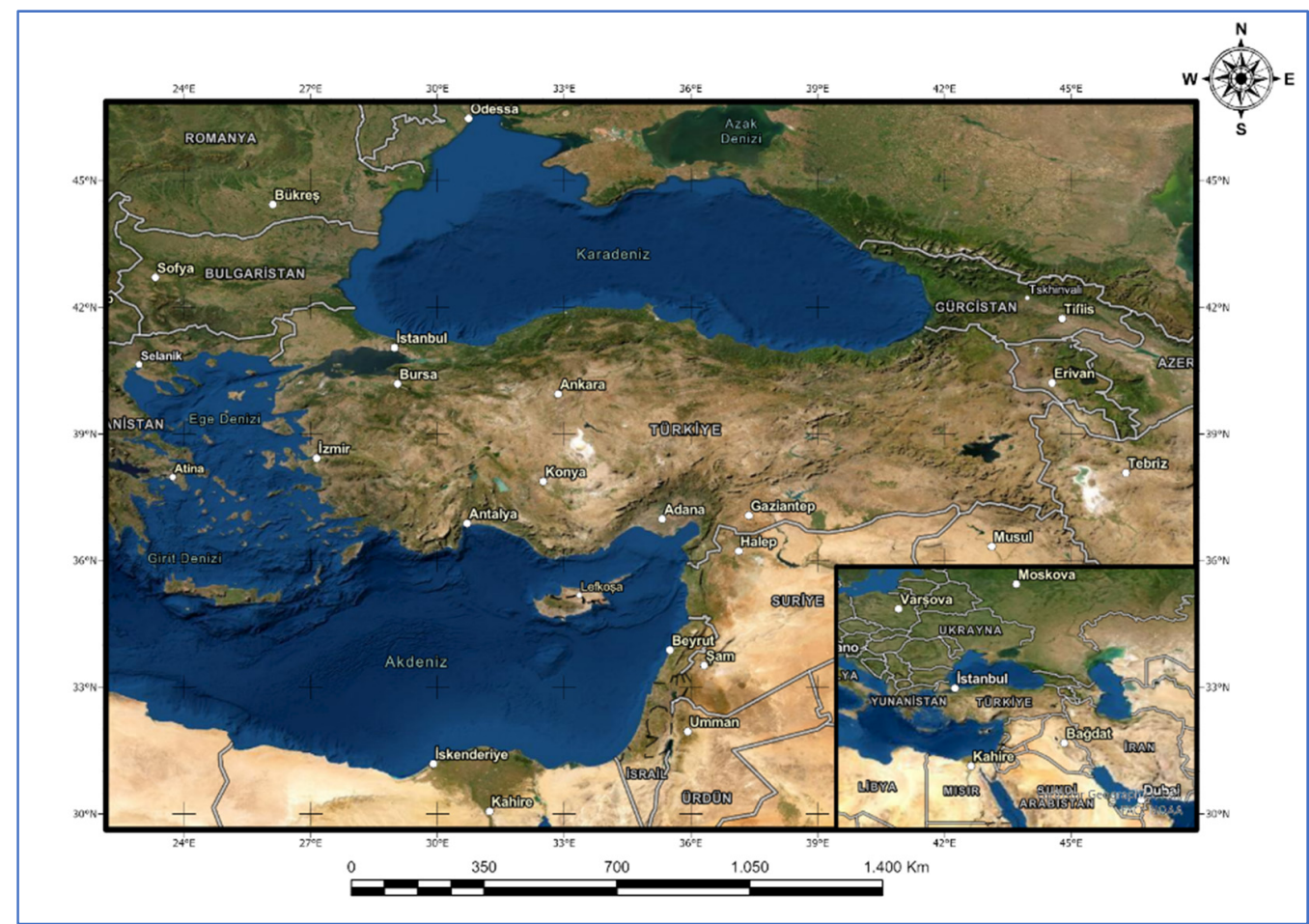

Figure 1. Geographical position of Turkey (produced by the use of ArcGIS Pro).

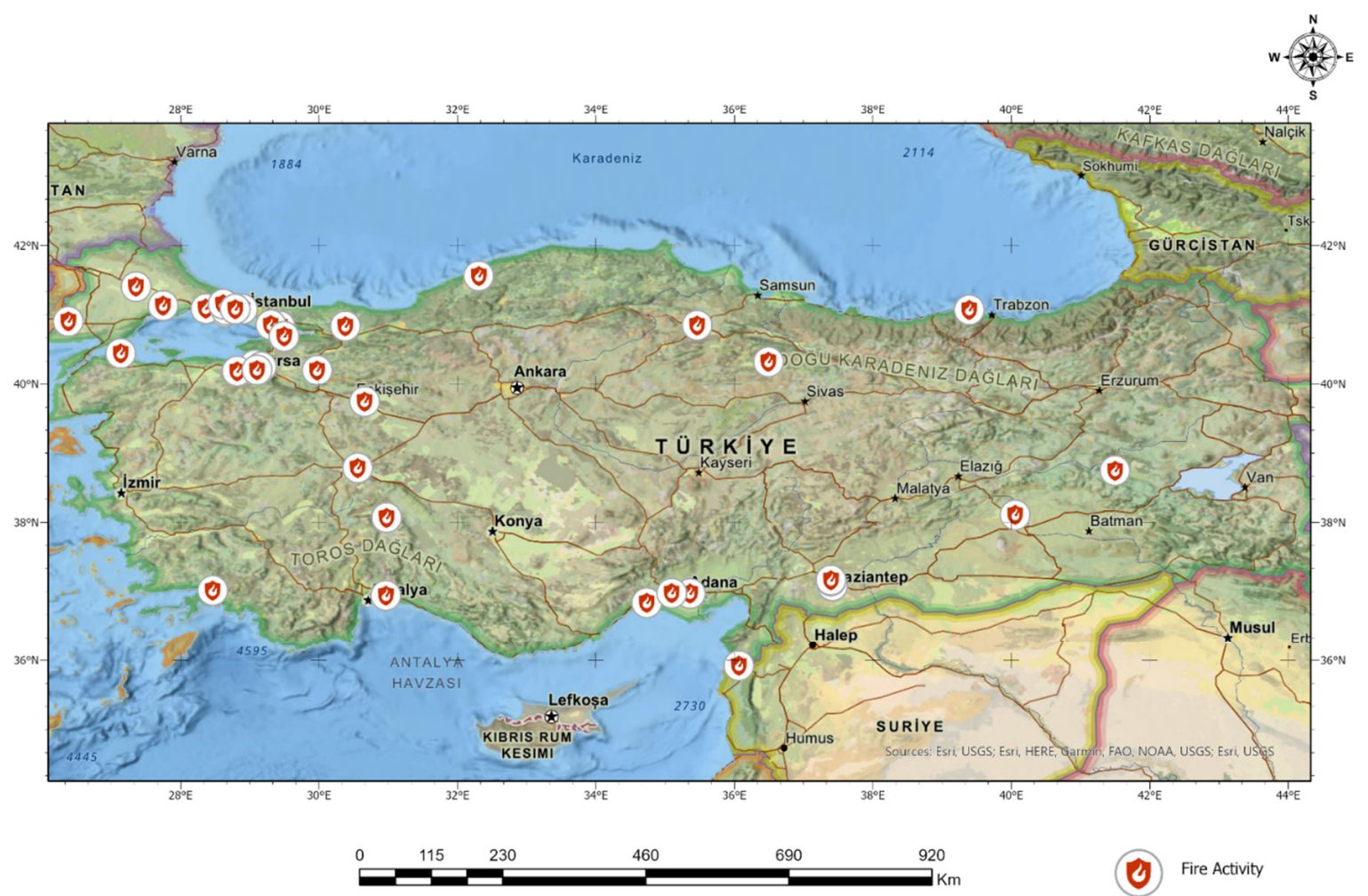

Figure 2. Location of fire cases. 
The present fire cases (40 fires) were all proven to be electric fires through surveillance footage, the identification of physical damage on materials, the destruction of heat and flames, and the statements of eyewitnesses. Death and injuries were not encountered in any of these fire cases. Criminal issues (intention) were also not encountered in any of these cases. The lowest temperature in the center of the fire was measured to be about $700{ }^{\circ} \mathrm{C}$, and the highest was measured to be about $1000-1100{ }^{\circ} \mathrm{C}$. The areas burned generally varied between 200 and $30,000 \mathrm{~m}^{2}$ but rose to $58,700 \mathrm{~m}^{2}$ in one case. The financial damage generally varied between $\$ 350,000$ and $\$ 53,000,000$, but there were two cases with financial damages of $\$ 194$ million and $\$ 662.5$ million. The financial damage values were taken from the damage assessment reports of insurance companies.

As compared to residential fires and the fires frequently encountered in shopping areas, the fire cases discussed here, similarly to their counterparts worldwide, as mentioned above, had greater dimensions. As can be inferred from the heat levels provided above, these fires progressed at high temperatures due to the abundance of materials with various heating values at the fires. Detailed information in the investigation reports is related to the course of the fires under the specific conditions of each case. Beyond shedding light on the solution in the course of a specific fire, such information may also act as an indicator of the potential risk, to be merged with the development of other conditions. For instance, in one particular fire case discussed in the present study, a fire investigation expert reported that pieces from the surface of the concrete started to come off, indicating that the temperature reached was at least $1000{ }^{\circ} \mathrm{C}$; this information is supported by the deformations encountered on other materials [25]. For example, copper pipes in cooling systems melted and dripped in some places, although they were not exposed to an electric current. It is known that this is an indicator of the temperature level in a fire place $\left(1084^{\circ} \mathrm{C}\right.$, melting point of copper).

The threshold damage levels of thermal radiation were reported as $4.7 \mathrm{~kW} / \mathrm{m}^{2}(14.5 \mathrm{~s})$ for human skin; $12.5-15 \mathrm{~kW} / \mathrm{m}^{2}$ for wooden and plastic materials; $12.6 \mathrm{~kW} / \mathrm{m}^{2}$ for buildings [26]; $37.5 \mathrm{~kW} / \mathrm{m}^{2}$ heat flux (10 s) for steel tanks, chemical production tools, and machines [27,28].

The emergence of such a great amount of heat is limited through the insufficient flammable materials left, thus reducing the specific heat production of the heat-generating center and removing convective heat dissipation through airflow and extinguishing and cooling activities. However, a scenario in favor of the fire may easily elevate the risks. Fires in industrial production facilities and large warehouses are quite different from residential fires; thus, the existence of critical factors able to enlarge fires should be taken into consideration. Therefore, the risks exerted on the surrounding environment in the current fire case were assessed in this study. The places included within the primary risk zone of such fires are those (hospitals, schools, gas stations, shopping centers, military installations, and transformer buildings) located at a short distance from the location of the fire. Hospitals are hard to evacuate quickly, as compared to several buildings and settlements, and there are special actions taken in this case [29,30]. Schools have large masses of different age groups, and these are not easy to manage in emergency cases. Whether the fire originated from the interior parts of the school or the fire threat is from a nearby place, the lack of emergency staff able to manage emergency cases and with no experience of initial extinguishing and rescue increases the risk potential of schools and similar places [31]. Shopping centers have shops such as restaurants with considerable flammable material loads and are crowded at certain hours; thus, it is rather hard to evacuate these areas in the case of a fire. In several places, hospitals, schools, and shopping centers, as critical buildings, are not constructed in a fashion that would facilitate their secure and fast evacuation. They are mostly designed to meet certain needs and different purposes. Such factors thus increase the risk potential of these buildings.

A fire generating a high heat load decomposes cooling and insulation materials and mineral oils (not flammable under normal conditions) used in transformers. Petroleumbased oils release hydrogen and methane gases at temperatures between 150 and $300^{\circ} \mathrm{C}$. 
Ethylene gas is released when the temperature reaches over $300^{\circ} \mathrm{C}$, and excessive ethylene and hydrogen gases are released when the temperature reaches over $700{ }^{\circ} \mathrm{C}$; an explosion may happen when the critical threshold for a fuel/air mixture increases to a flashing point (2.7\% for ethylene and $4 \%$ for hydrogen) [32].

Although precautions are taken against fires in gas stations, some fires that could take place around gas stations may generate high heat effects, posing serious risks to these places, similar to those of the cases considered in this study.

Military installations generally have limited building densities and facilities, such as materials and personnel, to deal with cases of crisis, including fires. However, such facilities were also taken into consideration among the surrounding places at risk. Since military installations are highly sensitive to security flaws, they should be placed away from buildings or facilities with the potential for large fires.

In the case of a BLEVE (Boiling Liquid Expanding Vapor Explosion) in industrial areas, production facilities, and factories - for instance, for a 12,000 L propane tank-the impact zone was calculated as $110 \mathrm{~m}$ for radiant heat, which is able to cause a second-degree burn; $850 \mathrm{~m}$ for missiles; and $68 \mathrm{~m}$ for blast waves [33]. These distances increase with increasing tank capacities. In dust explosions, the impact distance varies greatly based on the air density, compression, and dissipated volume of the combustible dust.

\subsection{Method}

Fire cases are complex phenomena involving various criteria. Such criteria make the analysis and overall study difficult. Therefore, a method facilitating multi-criteria analysis should be employed in such studies. Analytic Hierarchy Process (AHP), Topsis, Electre, Prometee, and similar methods are widely used in social science and engineering research [34-39]. Rajabi et al. used AHP when studying the occupational stressors of firefighters [34]. First, they identified the most important stressors using the Fuzzy Delphy method and determined their priorities with AHP. Gigovic et al. and Van Hoang et al. collected, analyzed, and monitored the data via GIS and weighted criteria and parameters using AHP [36,38]. Nyimbili and Erden also determined the weighted values of selected criteria for the recommendation of the best location for Urban Emergency Facilities in İstanbul using AHP [39]. The AHP model used in the present study is among the most common multi-criteria decision-making (MCDM) methods used. The model was developed by Saaty in 1980. AHP is a method allowing the comparison of multiple criteria [40]. It simplifies complex problems, facilitates the use of qualitative and quantitative methods, and is thus mostly preferred by researchers [36-39]. With the aid of AHP, expert personnel can become decision-makers and play an efficient role in the identification and weighting of criteria [37].

In this study, gas stations, schools, shopping centers, hospitals, electrical sub-stations, and military facilities within the close vicinity of fire cases in industrial facilities and warehouses were considered to be significant criteria. In addition, assessments were carried out according to the distances of certain facilities and structures located in the circular areas around the locations of fires. The flow chart used in this method is presented in Figure 3. In the identification of the criteria, independent questionnaires answered by a group of 12 expert personnel members with at least ten years of experience in fire-fighting were used. The results and weights were obtained with the use of the fishbone method [41]. An expert group was asked to score the questions for relevant criteria on a 1-9 scale (Table 1). In the AHP analysis, as can be seen in Table 2, two criteria were compared to each other through a pairwise comparison procedure on a 1-9 scale. Each criterion was compared. Weight coefficients $(\mathrm{w})$ were used for calculating the risky places according to the distances following this process for use in risk scoring tables. Consistency index (CI) and consistency ratio (CR) checks were carried out to determine the accuracy of the AHP. For six criteria, the random index (RI) was 1.24. (Table 3). The CI was calculated as 0.092, and the CR was calculated as $0.062(<10 \%)$. A CR value of $<0.1$ indicated that the AHP weight matrix was reliable and could be used in the present analysis. 


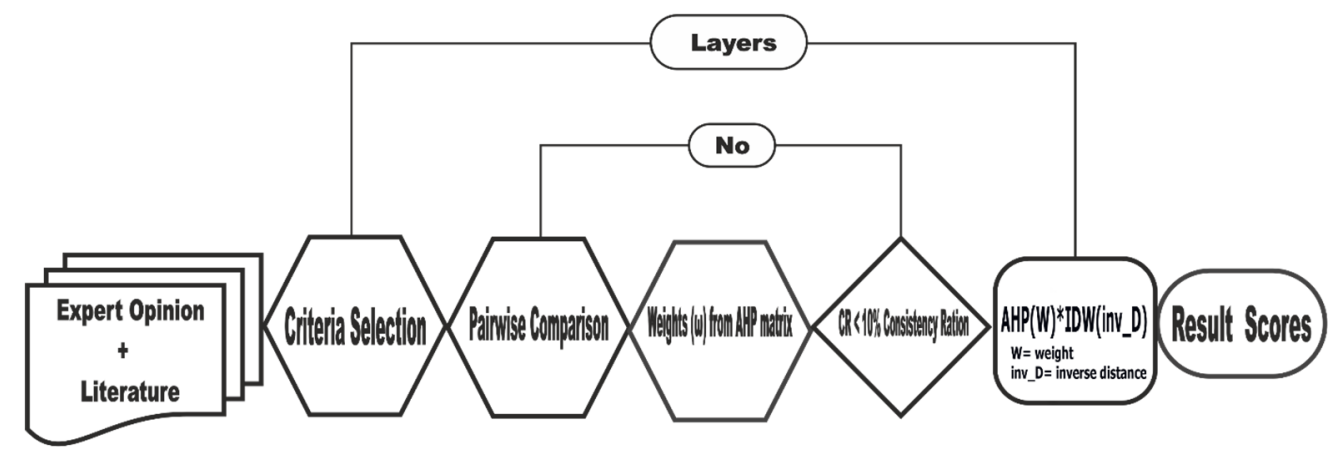

Figure 3. Analytic Hierarchy Process + Inverse Distance Way flow chart.

Table 1. Gradation scale for the quantitative comparison of criteria.

\begin{tabular}{cc}
\hline Option & Numerical Value(s) \\
\hline Equal & 1 \\
\hline Marginally strong & 3 \\
\hline Strong & 5 \\
\hline Very strong & 7 \\
\hline Extremely strong & 9 \\
\hline Intermediate values & $2,4,6,8$ \\
\hline
\end{tabular}

Table 2. AHP matrix and weights for each criterion.

\begin{tabular}{ccccccccc}
\hline & & School & Hospital & $\begin{array}{c}\text { Gas } \\
\text { Station }\end{array}$ & $\begin{array}{c}\text { Military } \\
\text { Facilities }\end{array}$ & $\begin{array}{c}\text { Electrical } \\
\text { Substation }\end{array}$ & $\begin{array}{c}\text { Shopping } \\
\text { Center }\end{array}$ \\
\cline { 2 - 9 } & & $\mathrm{A}$ & $\mathrm{B}$ & $\mathrm{C}$ & $\mathrm{D}$ & $\mathrm{E}$ & $\mathrm{F}$ & Weight (w) \\
\hline School & $\mathrm{A}$ & 1 & 0.17 & 0.14 & 0.50 & 3.00 & 2.00 & $\mathbf{0 . 0 7 0 4 5 4}$ \\
\hline Hospital & $\mathrm{B}$ & 6.00 & 1 & 0.50 & 3.00 & 8.00 & 7.00 & $\mathbf{0 . 2 9 3 1 3 5}$ \\
\hline Gas Station & $\mathrm{C}$ & 7.00 & 2.00 & 1 & 6.00 & 9.00 & 8.00 & $\mathbf{0 . 4 4 7 0 4 5}$ \\
\hline $\begin{array}{c}\text { Military } \\
\text { Facilities }\end{array}$ & $\mathrm{D}$ & 2.00 & 0.33 & 0.17 & 1 & 4.00 & 3.00 & $\mathbf{0 . 1 1 1 1 1 0}$ \\
\hline $\begin{array}{c}\text { Electrical } \\
\text { Substation }\end{array}$ & $\mathrm{E}$ & 0.33 & 0.13 & 0.11 & 0.25 & 1 & 0.50 & $\mathbf{0 . 0 3 1 6 9 0}$ \\
\hline Shopping Center & $\mathrm{F}$ & 0.50 & 0.14 & 0.13 & 0.33 & 2.00 & 1 & $\mathbf{0 . 0 4 6 5 6 4}$ \\
\hline TOTAL & $\mathrm{T}$ & $\mathbf{1 6 . 8 3}$ & $\mathbf{3 . 7 7}$ & $\mathbf{2 . 0 5}$ & $\mathbf{1 1 . 1 0}$ & $\mathbf{2 7 . 0 0}$ & $\mathbf{2 1 . 5 0}$ & $\mathbf{1}$ \\
\hline
\end{tabular}

Table 3. AHP validity reliability test.

\begin{tabular}{cccccccccc}
\hline $\mathbf{N}$ & $\mathbf{1}$ & $\mathbf{2}$ & $\mathbf{3}$ & $\mathbf{4}$ & $\mathbf{5}$ & $\mathbf{6}$ & $\mathbf{7}$ & $\mathbf{8}$ & $\mathbf{9}$ \\
\hline $\mathbf{R I}$ & 0.00 & 0.00 & 0.58 & 0.90 & 1.12 & 1.24 & 1.32 & 1.41 & 1.45 \\
\hline
\end{tabular}

RI: random index; CI: consistency index; CR: consistency ratio; $\mathrm{CI}=\frac{\lambda-\mathrm{N}}{\mathrm{N}-1} ; \mathrm{CR}=\frac{\mathrm{CI}}{\mathrm{RI}}$.

Beside the position of each fire case (Figure 2), the positions of schools, gas stations, and other places selected as criteria were marked on a map. Latitude-longitude data of such places were generated with the use of open-access interactive mapping services such as Google Maps, Yandex Map, Wikimapia, OpenStreetMap, Google Earth Pro, ArcGIS Pro, and Esri Map. Buffer maps were generated for schools, hospitals, and gas stations for each fire case with the use of GIS methods (see in Supplementary Materials). Then, the number of places related to the six criteria and their distance to the fire location were determined with Google Earth Pro at the 1/26.000 scale. (Figure 4). 


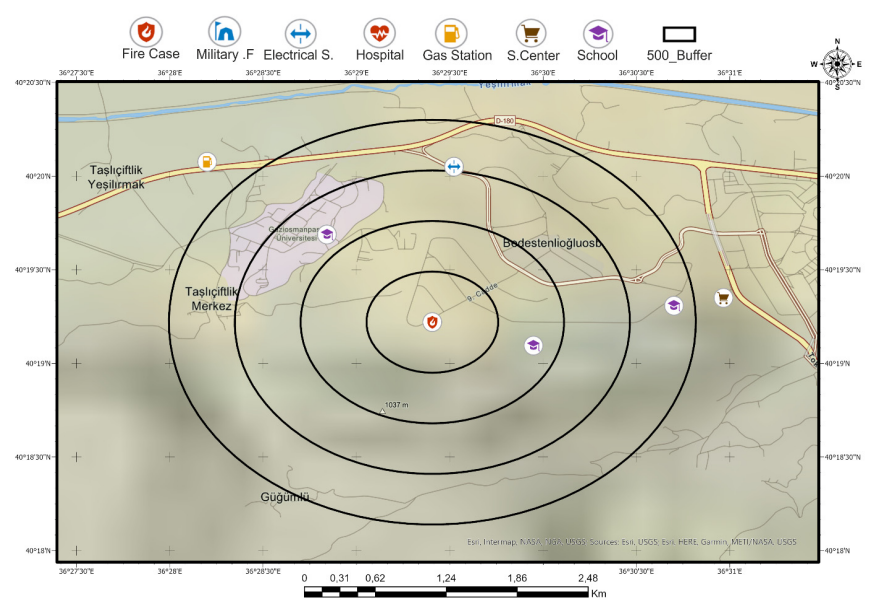

(a)

\begin{tabular}{|l|c|c|c}
\hline & distance1 & distance2 & distance3 \\
\hline School & $\mathbf{8 4 5}$ & 1145 & 1834 \\
\hline Hospital & & & \\
\hline Gas station & & & \\
\hline Military F. & & & \\
\hline Electrical S. & 1532 & & \\
\hline Shopping C. & & & \\
\hline
\end{tabular}

(c)

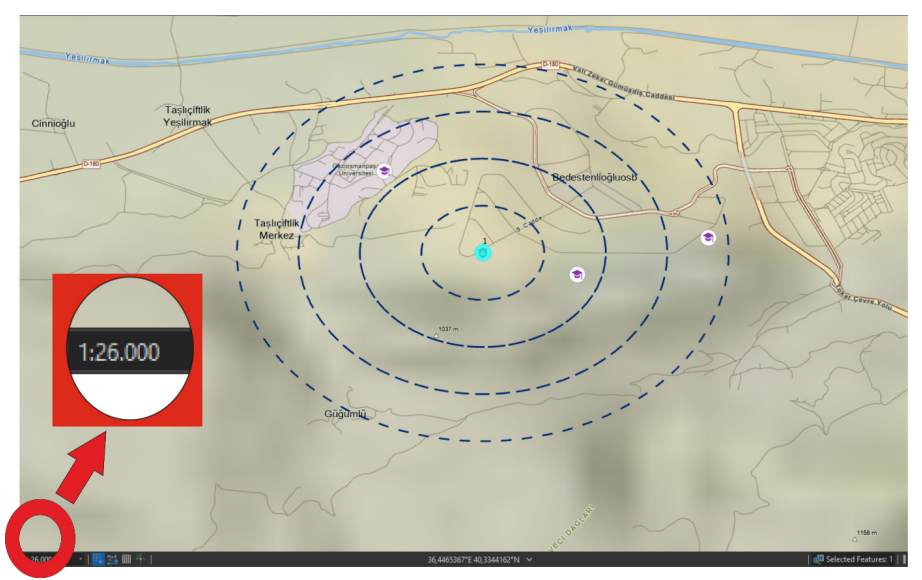

(b)

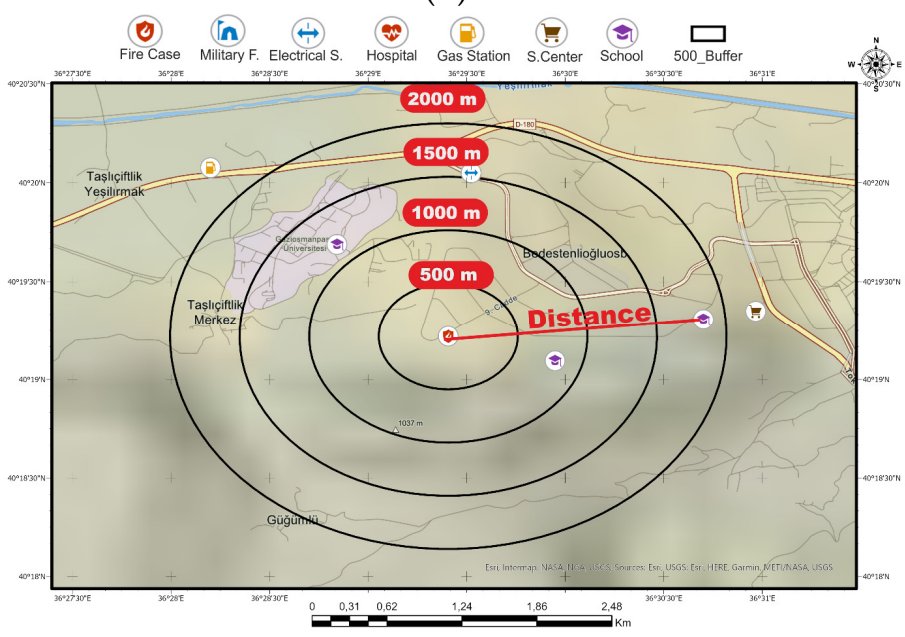

(d)

Figure 4. (a) Buffer map for fire case 1. (b) Map scale at distance measurement. (c) Measured distances of the risk criteria. (d) Measurement of distances.

It has been stated that the differences between Google Earth Pro measurements and the mean error of conventional measurements are approximately $5-9 \mathrm{~cm}$ at intervals of $30.5 \mathrm{~m}$ to $<76.2 \mathrm{~m}$, less than $1 \mathrm{~cm}$ until $150.4 \mathrm{~m}$, and almost zero at distances longer than $150.4 \mathrm{~m}$ [42]. In the analysis of repetitive distance measurement on the buffer maps generated for fire locations, the mean error and relative error were determined as $1.63 \mathrm{~cm}$ and 0.000008861 , respectively. This is a rather reasonable amount of deviation and a high accuracy for distances in fire scenes that were scaled in meters. The measured distances at this stage were converted to weights by the Inverse Distance Weight (IDW) method. The IDW method is a simple spatial interpolation method [43]. This method is based on the fact that the nearby points on the surface have higher weights than the distant points [44]. The following formula was used:

$$
\mathrm{W}_{\mathrm{p}}=\frac{\sum_{\mathrm{i}=1}^{\mathrm{m}} \frac{\mathrm{z}_{\mathrm{i}}}{\mathrm{d}_{\mathrm{i}}^{\mathrm{n}}}}{\sum_{\mathrm{i}=1}^{\mathrm{m}} \frac{1}{\mathrm{~d}_{\mathrm{i}}^{\mathrm{n}}}}
$$

where $z_{i}$ represents the weight at point $i$-that is, the weight value $(w)$ of a school or hospital; $d_{i}^{n}$ the distance; and $w_{p}$ the effect at distance $d_{i}$. In preliminary studies, since the method was shown to be sufficient for the discrimination of the effect of distance, the calculation was carried out accepting that $n=1$. The weighted values found by the IDW method are given in Table 4 . The weights of the criteria, of which the priorities were 
assessed by AHP, were determined again according to the distance to the location of the fire. The IDW model was generated in a distance scale at the locations of fires according to the IDW weights. According to the trends of the graphics of the model, the distances of structures and facilities, determined as criteria around fire places, were obtained. The plot in Figure 5 shows their decreasing trends effect with the increasing distance of the criteria. The risk scores obtained using this approach of calculating the weights of the distance to the location of a fire are presented in Table 5 .

Table 4. Weighting of the AHP weights by IDW based on the distance.

\begin{tabular}{|c|c|c|c|c|c|c|c|c|c|c|}
\hline & \multirow[b]{2}{*}{$\begin{array}{l}\text { Weight } \\
\text { (AHP) }\end{array}$} & \multirow[b]{2}{*}{$\begin{array}{c}\text { Distance(d) } \\
\text { (m) }\end{array}$} & \multirow[b]{2}{*}{$1 / d$} & \multirow[b]{2}{*}{$\begin{array}{l}\text { Weight } \\
\text { (IDW) }\end{array}$} & \multicolumn{6}{|c|}{ Weighted Values of Criteria } \\
\hline & & & & & School & Hospital & $\begin{array}{c}\text { Gas } \\
\text { Station }\end{array}$ & $\begin{array}{c}\text { Military } \\
\text { Facilities }\end{array}$ & $\begin{array}{l}\text { Electrical } \\
\text { Substation }\end{array}$ & $\begin{array}{l}\text { Shopping } \\
\text { Center }\end{array}$ \\
\hline School & 0.0705 & 50 & 0.02000 & 0.6076 & 0.0428 & 0.1781 & 0.2716 & 0.0675 & 0.0193 & 0.0283 \\
\hline Hospital & 0.2931 & 150 & 0.00670 & 0.2025 & 0.0143 & 0.0594 & 0.0905 & 0.0225 & 0.0064 & 0.0094 \\
\hline Gas station & 0.4470 & 300 & 0.00330 & 0.1013 & 0.0071 & 0.0297 & 0.0453 & 0.0113 & 0.0032 & 0.0047 \\
\hline $\begin{array}{l}\text { Military } \\
\text { facilities }\end{array}$ & 0.1111 & 600 & 0.00170 & 0.0506 & 0.0036 & 0.0148 & 0.0226 & 0.0056 & 0.0016 & 0.0024 \\
\hline $\begin{array}{c}\text { Electrical } \\
\text { substation }\end{array}$ & 0.0317 & 1200 & 0.00083 & 0.0253 & 0.0018 & 0.0074 & 0.0113 & 0.0028 & 0.0008 & 0.0012 \\
\hline $\begin{array}{c}\text { Shopping } \\
\text { center }\end{array}$ & 0.0466 & 2400 & 0.00042 & 0.0127 & 0.0006 & 0.0037 & 0.0057 & 0.0014 & 0.0004 & 0.0006 \\
\hline Total & 1 & & & 1 & 0.0702 & 0.2931 & 0.4470 & 0.1111 & 0.0317 & 0.0466 \\
\hline
\end{tabular}

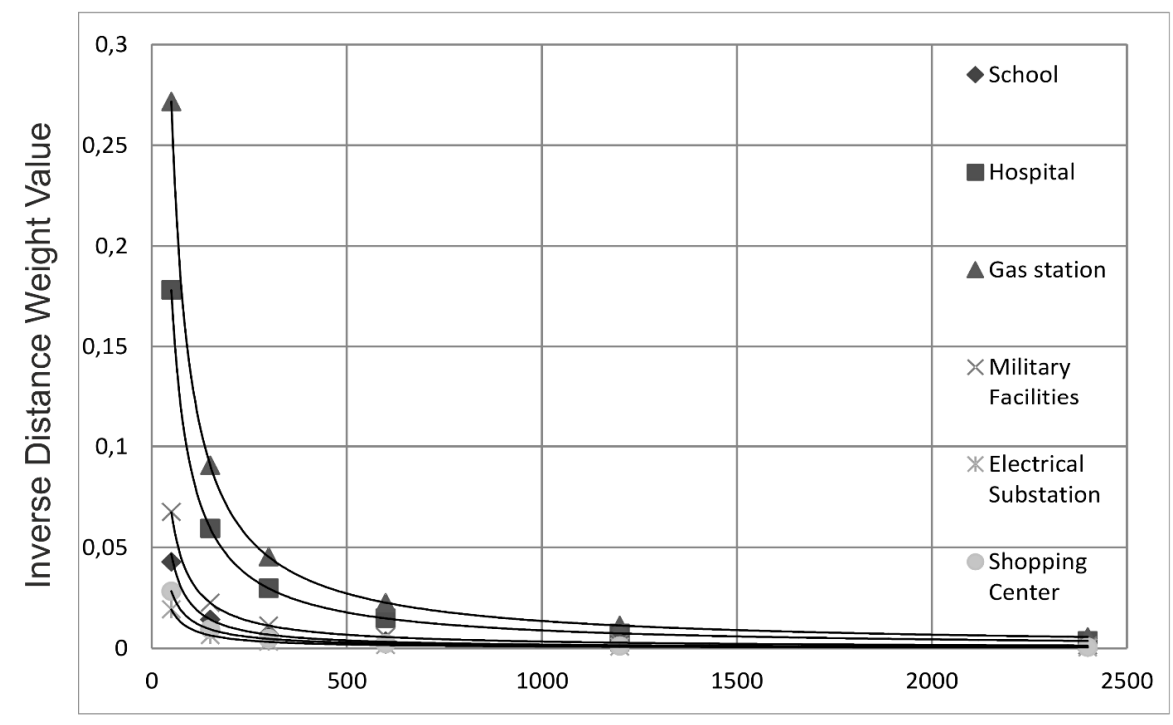

Distance

Figure 5. Weight decrease with distance.

Table 5. Risk scores calculated for all fire cases.

\begin{tabular}{|c|c|c|c|c|c|c|c|c|}
\hline \multirow[b]{2}{*}{$\begin{array}{l}\text { Fire } \\
\text { Case }\end{array}$} & \multirow[b]{2}{*}{$\begin{array}{l}\text { Risk } \\
\text { Score }\end{array}$} & \multicolumn{6}{|c|}{ Number of Criteria in Buffer Zones Surrounding the Fire Cases } & \multirow[b]{2}{*}{ Industry Sector } \\
\hline & & School & Hospital & $\begin{array}{c}\text { Gas } \\
\text { Station }\end{array}$ & $\begin{array}{l}\text { Military } \\
\text { Facilities }\end{array}$ & $\begin{array}{c}\text { Electrical } \\
\text { Substation }\end{array}$ & $\begin{array}{c}\text { Shopping } \\
\text { Center }\end{array}$ & \\
\hline 21 & 0.8657 & 29 & 8 & 9 & & & & TechTextile production \\
\hline 32 & 0.3797 & 13 & 9 & 8 & & & 6 & $\begin{array}{c}\text { Cold storage of agricultural } \\
\text { products }\end{array}$ \\
\hline 17 & 0.3305 & 15 & 10 & 4 & & & 2 & Furniture and textile \\
\hline 31 & 0.3182 & 13 & 10 & 3 & & & 8 & Shoe production \\
\hline 39 & 0.1758 & 20 & 7 & 5 & & 2 & 6 & Textile fabric \\
\hline
\end{tabular}


Table 5. Cont

\begin{tabular}{|c|c|c|c|c|c|c|c|c|}
\hline \multirow[b]{2}{*}{$\begin{array}{l}\text { Fire } \\
\text { Case }\end{array}$} & \multirow[b]{2}{*}{$\begin{array}{l}\text { Risk } \\
\text { Score }\end{array}$} & \multicolumn{6}{|c|}{ Number of Criteria in Buffer Zones Surrounding the Fire Cases } & \multirow[b]{2}{*}{ Industry Sector } \\
\hline & & School & Hospital & $\begin{array}{c}\text { Gas } \\
\text { Station }\end{array}$ & $\begin{array}{c}\text { Military } \\
\text { Facilities }\end{array}$ & $\begin{array}{c}\text { Electrical } \\
\text { Substation }\end{array}$ & $\begin{array}{l}\text { Shopping } \\
\text { Center }\end{array}$ & \\
\hline 4 & 0.1668 & 15 & 6 & 3 & & & & Food production \\
\hline 36 & 0.1553 & 14 & 6 & 3 & & & & $\begin{array}{l}\text { Plastic items and PET bottle } \\
\text { production }\end{array}$ \\
\hline 23 & 0.1252 & 4 & 3 & 3 & 1 & & 3 & Sea products storage \\
\hline 40 & 0.1204 & 8 & 2 & 4 & 1 & 1 & 1 & Shoe and leather industry \\
\hline 34 & 0.1174 & 7 & 5 & & & 1 & 4 & Home appliance industry \\
\hline 16 & 0.1115 & 13 & 6 & 1 & & & 3 & Plastic items production \\
\hline 27 & 0.1027 & 3 & & 3 & & & 1 & Shoe production \\
\hline 2 & 0.1007 & 13 & 1 & 5 & & 1 & 1 & Meat products industry \\
\hline 24 & 0.1000 & 1 & & 2 & & & & $\begin{array}{l}\text { Cold storage of agricultural } \\
\text { products }\end{array}$ \\
\hline 25 & 0.0989 & & & 2 & & & & $\begin{array}{l}\text { Cold storage of agricultural } \\
\text { products }\end{array}$ \\
\hline 8 & 0.0902 & 10 & 2 & 3 & & & 6 & Food production \\
\hline 13 & 0.0901 & 2 & 4 & 2 & & 2 & 2 & Textile fabric \\
\hline 28 & 0.0877 & 8 & & 5 & & & 4 & Wood structure production \\
\hline 38 & 0.0723 & & & 5 & & & 1 & Metalworks industry \\
\hline 11 & 0.0695 & 12 & & 4 & & & & $\begin{array}{l}\text { Cold storage of agricultural } \\
\text { products }\end{array}$ \\
\hline 22 & 0.0567 & 6 & 2 & 1 & 1 & & 3 & Logistics depots \\
\hline 26 & 0.0560 & 6 & 2 & 1 & 1 & & 3 & $\begin{array}{l}\text { Cold storage of agricultural } \\
\text { products }\end{array}$ \\
\hline 6 & 0.0523 & 2 & 1 & & & & & Cold storage of citrus fruits \\
\hline 20 & 0.0422 & 2 & & 2 & & & 1 & Shoe production \\
\hline 19 & 0.0404 & 1 & & 4 & & 1 & & Carpet manufacture \\
\hline 18 & 0.0297 & 2 & & 2 & & & & Cold storage of legumes \\
\hline 15 & 0.0295 & 2 & & 1 & & & 1 & $\begin{array}{l}\text { Wooden furniture } \\
\text { manufacture }\end{array}$ \\
\hline 12 & 0.0282 & 3 & 1 & 1 & & & & Ceramic manufacture \\
\hline 7 & 0.0230 & & & 2 & & & & $\begin{array}{l}\text { Cold storage of agricultural } \\
\text { products }\end{array}$ \\
\hline 37 & 0.0229 & 1 & 1 & & & & & Bicycle manufacture \\
\hline 14 & 0.0218 & & & 1 & & 1 & 1 & Glass items manufacture \\
\hline 3 & 0.0196 & 7 & & 1 & & & 1 & Sea products storage \\
\hline 9 & 0.0129 & 2 & 1 & & & & & $\begin{array}{l}\text { Cold storage of agricultural } \\
\text { products }\end{array}$ \\
\hline 1 & 0.0098 & 3 & & & & 1 & & Supermarket warehouse \\
\hline 29 & 0.0094 & & & 1 & & & 2 & Energy industry \\
\hline 35 & 0.0067 & 2 & & & & & & $\begin{array}{l}\text { Plastic items and PET bottle } \\
\text { production }\end{array}$ \\
\hline 10 & 0.0016 & 1 & & & & & & Cold storages and warehouses \\
\hline 5 & 0 & & & & & & & Package materials production \\
\hline 30 & 0 & & & & & & & Sustainable energy industry \\
\hline 33 & 0 & & & & & & & energy and steel industry \\
\hline
\end{tabular}

\section{Results and Discussion}

Risk scores represent the potential risk posed by each fire case to the surrounding environment. In terms of these risk scores, fire case 21 was identified as the riskiest case, as can be seen in Table 5. Fire case 21 concerned a textile manufacturing and trade factory; an area of $1700 \mathrm{~m}^{2}$ was burned with a total financial damage of $\$ 1,600,000$. It can easily be seen that it has a large amount of polymeric row material. There are two gas stations very close ( 54 and $56 \mathrm{~m}$ ) to the fire case (Figures 6 and 7). The next fire case, number 32, was a large warehouse for agricultural products, which resulted in a financial damage of 
$\$ 335,000$. There was one hospital (189 m), two gas stations (166 m and $390 \mathrm{~m}$ ), three schools, and one shopping center (590 $\mathrm{m}$ on average) around the fire case (Figure 8 ).

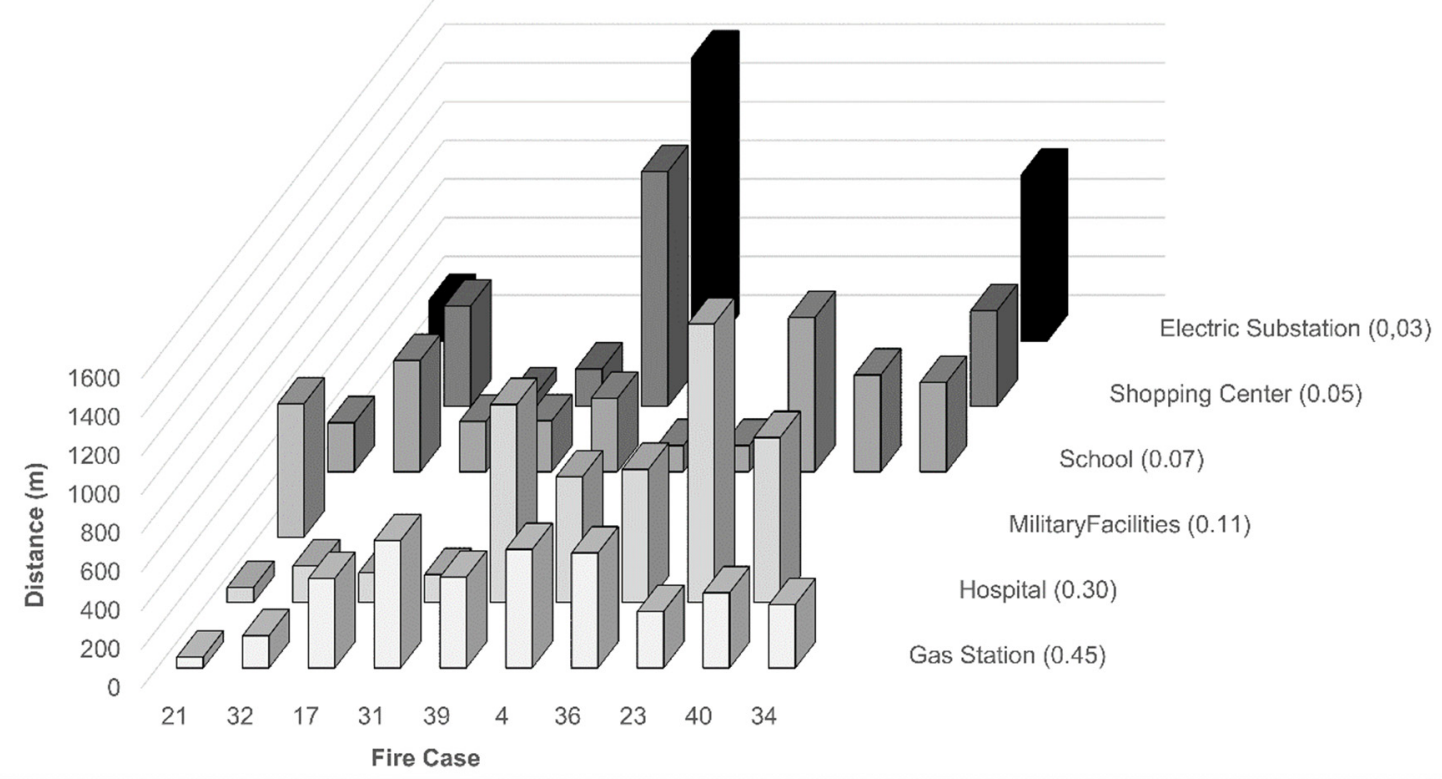

Figure 6. Distances of criteria of the first 10 fire cases at Table 5.

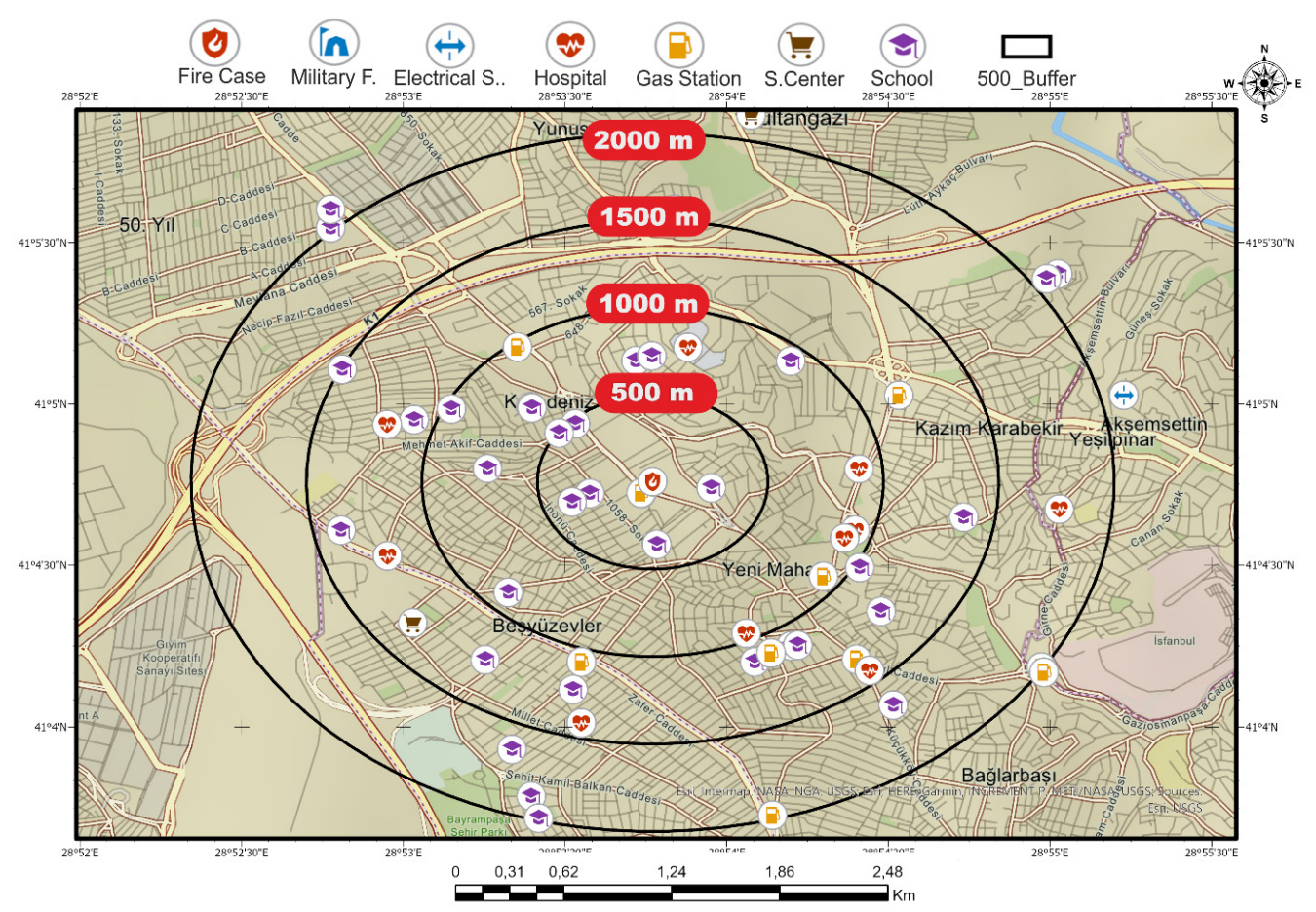

Figure 7. Buffer map of fire case 21.

According to Table 5, these 40 fire cases can be divided into several groups. These groups are high risk $(1-0.8)$, low risk $(0.4-0.1)$, and riskless $(<0.1)$. No fire case with scores between 0.7 and 0.5 were seen among them. The effect of AHP on the weight values of places at risk is considerable. For example, the factors observed in fire case 21 which elevate the risk score to 0.86 are not only the existence of two gas stations within a $50 \mathrm{~m}$ distance, but also the fact that the stations are in close proximity. On the other hand, two schools existing at distances of $130 \mathrm{~m}$ and $140 \mathrm{~m}$ from fire case 36 have an increase in risk score 
of only 0.046 points. This is because an AHP weight is 0.07 for a school but 0.45 for a gas station. Thus, the contribution to the total would be 0.2 points if there were two gas stations instead of two schools at the same distance from that fire case. The existence of two gas stations at a very close distance made a contribution of 0.5 points in total to the risk score in fire case 21. It was mentioned in Section 2.2 that experts' opinions were obtained by rating the answers given directly to the questions about fire scenes in a numerical way. With regard to the result mentioned above, it should be found that the effect of the data collected for AHP weights was reflected in the risk scores realistically.

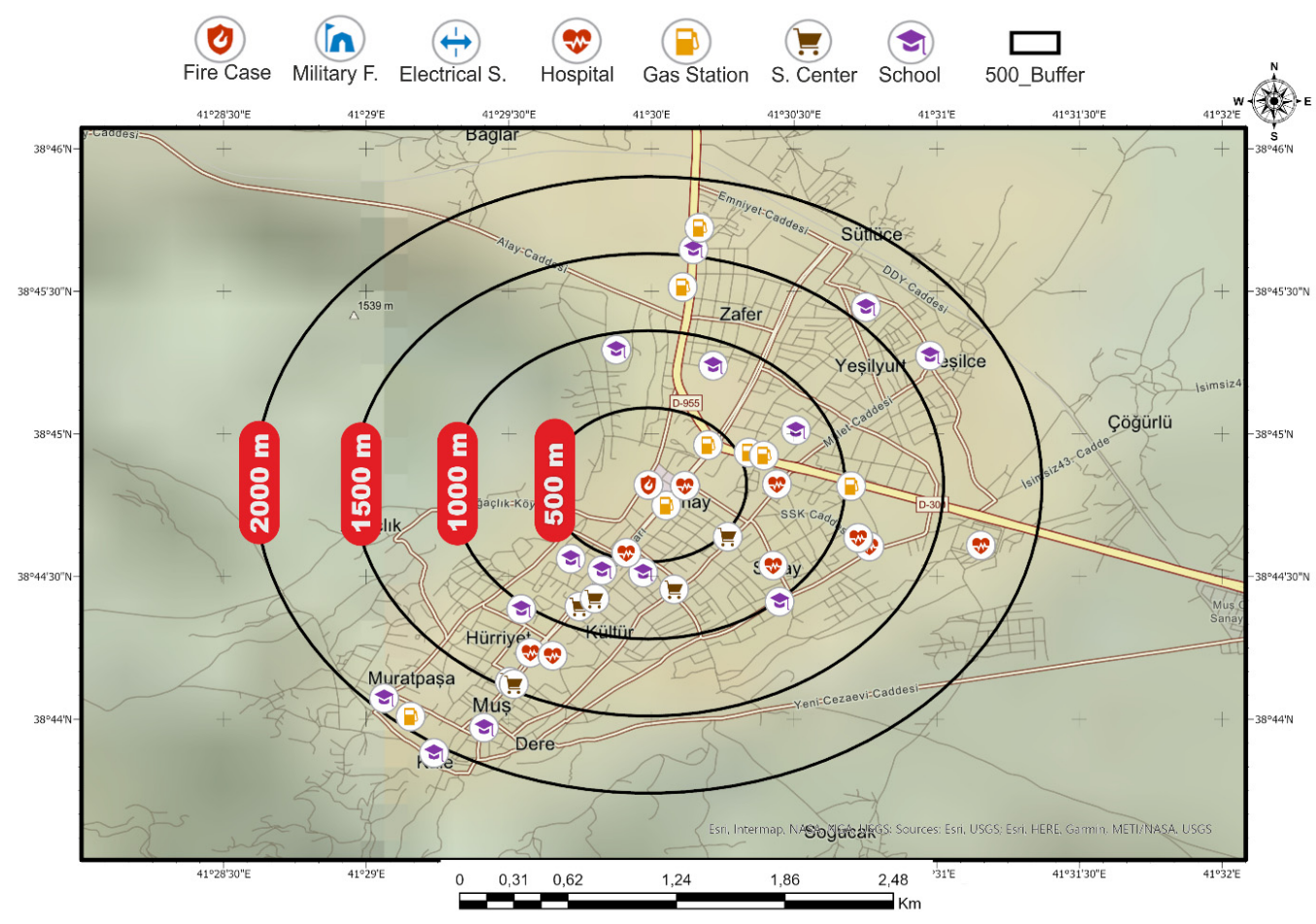

Figure 8. Buffer map of fire case 32.

The estimation of different criteria with a high accuracy is thus one of the abilities of the AHP method. This can be used to convert qualitative observations and expert judgements into quantitative information. It should be emphasized that the experts who contributed to this study treated the risk subject as people technically qualified for intervening in the fire. Additionally, possible domino effects were considered besides the factors involved in the propagation of a fire, such as heat, smoke, and explosions at the places exposed to the fire and around it. For instance, among the fires with a low risk score, fire case 18 involved two gas stations at a $1000 \mathrm{~m}$ distance (Figure 9). One can consider the distance as great, meaning that the probability of the fire reaching the area is very low. However, in the case of the conversion to a wildland fire via spreading to dried grass in hot and dry weather, along with the effect of the wind, it is highly possible that the fire can propagate too fast for the intervention activities to reach it. Thus, a $1000 \mathrm{~m}$ distance is likely to be very short for such a fire. Additionally, for other reasons, the AHP weights of gas stations were among the most important criteria considered, although these places have superior precautions. This is because they have a great potential to enlarge a fire by the domino effect. Sharrif et al. (2016) indicated that, in a BLEVE, the radiant heat effect, blast waves, and impact distance of missiles increased with increasing propane tank volumes-for instance, a missile may reach a distance of $2000 \mathrm{~m}$ in the explosion of a 45,460 L propane tank. Similar increments for such effects are highly probable, and this would exacerbate the impact on the environment.

The criteria were compared numerically according to the difference between distances for each fire case using the IDW method along with the AHP. It must be stated that this 
method has been applied for only 40 fire cases, providing a complete data set at this point. Data from another fire case added to this model would increase the number of processed fire cases; thus, it would be possible to increase the criteria as well.

The fire cases shown in Table 5 are observed to decrease from 0.176 points for fire case 39 to 0 points. In terms of the decrease in the number of points at the high AHP weights surrounding these events and the increases in their distances, there has been a decline in risk points.

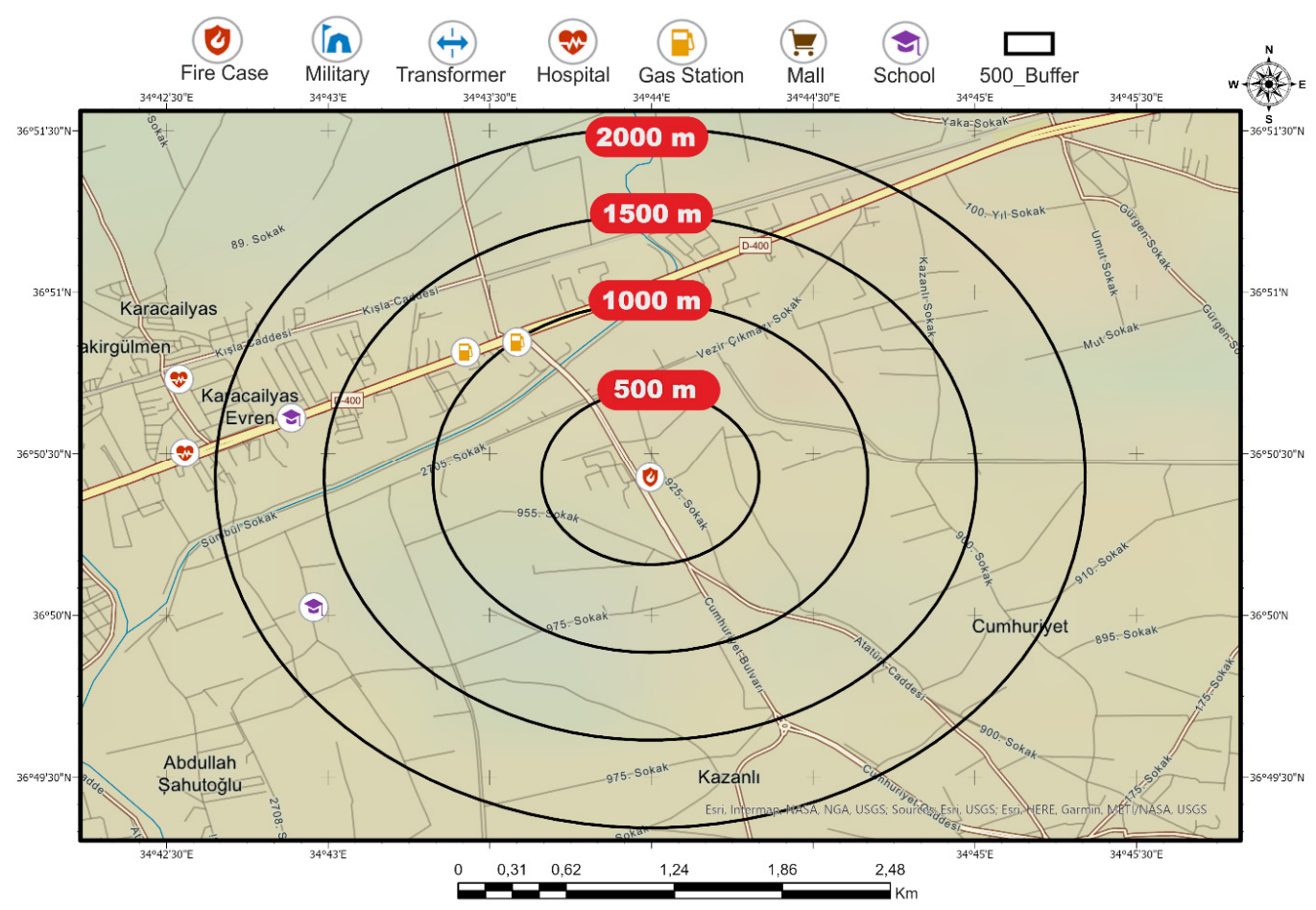

Figure 9. Buffer map of fire case 18.

Some of the fires discussed in this study were extinguished by firefighter teams before they could propagate. Some of them did not have the chance to propagate due to certain factors. Each fire case had different conditions and their own story with particular details. However, the "risk scores" indicated that there could be highly diverse scenarios, and the financial damage could have showed sharply increasing trends because of the surrounding facilities. Fire case 21 represents this danger increasing most obviously. Since there are various factors influencing these fire cases, there might be some quite different scenarios for different courses of fire. Already realized and analyzed fire cases were included in this study, and there might be different scenarios for the progress of fire due to the effects of different factors. The present fire cases initially resulted from electrical systems, as indicated before. However, they were quite different in terms of the size of the burned area, the damage level, the temperature level reached in the center of the fire, and the characteristics of the burned materials. Since these places were production facilities, warehouses, and large cold storage facilities, they were in continuous dynamic activity. The materials housed and their quantities may have changed daily, weekly, or even in a single day. The type and quantity of flammable materials involved, their positions, and their distances may greatly influence the fire scenario that developed.

\section{Conclusions}

The calculated risk levels indicate the potential risks of fires that can occur in different fashions in the same place and environment in the future, rather than the risk of those that are in progress or that have happened in the past. This model may also be applied to other places that have not experienced fires and reveal the risks of potential fires. In this way, the 
risk exerted on the environment by such a place may also be estimated. Different criteria could also be incorporated into the model, and such models could be used as a part of fire prevention efforts in different regions.

If the main purpose of a factory or production plant is dealing with chemical materials or petroleum, this is perceived to be dangerous by many people, and the first risk considered is fire. It was revealed in this study that the degree of danger of fires having taken place in industrial areas, which do not belong to the class mentioned just above, would not remain as small from time to time. Thus, this study was carried out using the information of places exposed to fires. Even if strict evidence was not provided for the danger caused by facilities not usually regarded as dangerous, it was clarified that fires can occur at any time.

This approach may be used efficiently in other fire cases or pre-fire assessments. It may also enable insurance companies to assess the risk of fire while ensuring that there are facilities to manage fires and calculate insurance premiums.

Supplementary Materials: The following are available online at https://www.mdpi.com/article/ 10.3390 / fire4030053/s1: Figure S1: Buffer map for fire case 1; Figure S2: Buffer map for fire case 2; Figure S3: Buffer map for fire case 3; Figure S4: Buffer map for fire case 4 and 36; Figure S5: Buffer map for fire case 5; Figure S6: Buffer map for fire case 6 and 37; Figure S7: Buffer map for fire case 7; Figure S8: Buffer map for fire case 8; Figure S9: Buffer map for fire case 9; Figure S10: Buffer map for fire case 10; Figure S11: Buffer map for fire case 11; Figure S12: Buffer map for fire case 12; Figure S13: Buffer map for fire case 13; Figure S14: Buffer map for fire case 14; Figure S15: Buffer map for fire case 15; Figure S16: Buffer map for fire case 16; Figure S17: Buffer map for fire case 17; Figure S18: Buffer map for fire case 18; Figure S19: Buffer map for fire case 19; Figure S20: Buffer map for fire case 20; Figure S21: Buffer map for fire case 21; Figure S22: Buffer map for fire cases 22 and 26; Figure S23: Buffer map for fire case 23; Figure S24: Buffer map for fire case 24; Figure S25: Buffer map for fire case 25; Figure S26: Buffer map for fire case 27; Figure S27: Buffer map for fire case 28; Figure S28: Buffer map for fire case 29; Figure S29: Buffer map for fire case 30; Figure S30: Buffer map for fire case 31; Figure S31: Buffer map for fire case 32; Figure S32: Buffer map for fire case 33; Figure S33: Buffer map for fire case 34; Figure S34: Buffer map for fire case 35; Figure S35: Buffer map for fire case 38; Figure S36: Buffer map for fire case 39; Figure S37: Buffer map for fire case 40; Describing of AHP formulation.

Author Contributions: Conceptualization, K.A. and E.A.; methodology and software, E.A.; investigation, S.A. and K.A.; data curation, S.A. and K.A.; writing-original draft preparation, K.A.; writing - review and editing, K.A. All authors have read and agreed to the published version of the manuscript.

Funding: This research received no external funding.

Institutional Review Board Statement: Not applicable.

Informed Consent Statement: Not applicable.

Data Availability Statement: Not applicable.

Acknowledgments: The authors express their thanks to experienced firefighters of the Fire Brigade Department of Antalya Metropolitan Municipality for their responses to the questionnaire forms prepared for the identification and quantitative assessment of criteria.

Conflicts of Interest: The authors declare no conflict of interest.

\section{References}

1. Statistics. İstanbul Metropolitan Municipality Department of Fire Brigade. 2020. Available online: http://itfaiye.ibb.gov.tr/img/ 1459582112020_1383325458.pdf (accessed on 20 August 2021). (In Turkish)

2. Statistics. İstanbul Metropolitan Municipality Department of Fire Brigade. Available online: https://itfaiye.izmir.bel.tr/en/ istatislik/7/152 (accessed on 11 March 2021). (In Turkish).

3. Peksen, M.F.; Uyaroglu, Y.; Soyhan, H.S. İstanbul, Ankara ve Sakarya illerinin 2018 yılı itfaiye olaylarının karşılaştırılması. Fuels Fire Combust. Eng. J. 2020, 8, 1-19.

4. Campbell, R. Fires in Industrial and Manufacturing Properties; National Fire Protection Association: Quincy, MA, USA, 2018. 
5. Facts + Statistics. Insurance Information Institute. Available online: https://www.iii.org/fact-statistic/facts-statistics-fire (accessed on 26 June 2021).

6. Mittal, M.; Guha, B.K. Industrial fires and explosions due to electrostatic ignition. Chem. Eng. Technol. 1993, 16, 325-331. [CrossRef]

7. Yuan, Z.; Khakzad, N.; Khan, F.; Amyotte, P. Dust explosions: A threat to the process industries. Process. Saf. Environ. Prot. 2015, 98, 57-71. [CrossRef]

8. Joseph, G.; CSB Hazard Investigation Team. Combustible dusts: A serious industrial hazard. J. Hazard. Mater. 2007, 142, 589-591. [CrossRef]

9. Bekar, İ.; Tavsanoglu, C.; Pezatti, G.B.; Vacik, H.; Pausas, J.G.; Bugmann, H.; Petter, G. Cross-regional modelling of fire occurrence in the Alps and Mediterranean Basin. Int. J. Wildland Fire 2020, 29, 712. [CrossRef]

10. Modugno, S.; Baltzer, H.; Cole, B.; Borelli, P. Mapping regional patterns of large fires in Wildland-Urban İnterface areas in Europe. J. Environ. Manag. 2016, 172, 112-126. [CrossRef] [PubMed]

11. Gungoroglu, C. Determination of forest fire risk with fuzzy analytic hierarchy process and its mapping with the application of GIS: The case of Turkey/Çakırlar. Hum. Ecol. Risk Assessment Int. J. 2017, 23, 388-406. [CrossRef]

12. Akay, A.E.; Erdogan, A. GIS-based multi-criteria decision analysis for forest fire risk mapping. ISPRS Annals of the Photogrammetry, Remote Sensing and Spatial Information Sciences. In Proceedings of the 4th International GeoAdvances Workshop, Safranbolu, Karabuk, Turkey, 14-15 October 2017; Volume IV-4/W4. [CrossRef]

13. Eskandari, S.; Miesel, J.R.; Pourghasemi, H.R. The temporal and spatial relationship between climatic parameters and fire occurence in northeastern Iran. Ecol. Indic. 2020, 118, 106720. [CrossRef]

14. Vadrevu, K.P.; Eaturu, A.; Badarinath, K.V.S. Fire risk evaluation using multicriteria analysis—a case study. Environ. Monit. Assess. 2010, 166, 223-239. [CrossRef]

15. Gheshlaghi, H.A.; Bakhtiar, F.; Blaschke, T. GIS-based forest risk mapping using the analytical network process and fuzzy logic. J. Environ. Plan. Manag. 2020, 63, 481-499. [CrossRef]

16. Chu, G.Q.; Chen, T.; Sun, Z.H.; Sun, J.H. Probabilistic risk assessment for evacuees in building fires. Build. Environ. 2007, 42, 1283-1290. [CrossRef]

17. An-Lee, C.; Sung, Y.C.; Lin, Y.S.; Hsiao, G.L.K. Evaluating the severity of building fires with the analytical hierarchy process, big data analysis and remote sensing. Nat. Hazards 2020, 103, 1843-1856. [CrossRef]

18. Coban, H.O.; Erdin, C. Forest fire risk assessment using GIS and AHP integration in Bucak forest enterprise, Turkey. Appl. Ecol. Environ. Res. 2020, 18, 1567-1583. [CrossRef]

19. Ji, J.; Tong, Q.; Khan, F.; Dadaszadeh, M.; Abbasi, R. Risk-based domino effect analysis for fire and explosion accidents considering uncertainty in processing facilities. Ind. Eng. Chem. Res. 2018, 57, 3990-4006. [CrossRef]

20. Khan, F.I.; Abbasi, S.A. Models for domino effect analysis in chemical process industries. Process. Saf. Prog. 1998, 17, 107-123. [CrossRef]

21. Antonioni, G.; Spadoni, G.; Cozzani, V. Application of domino effect quantitative risk assessment to an extended industrial area. J. Loss Prev. Process. Ind. 2009, 22, 614-624. [CrossRef]

22. Changa, J.I.; Linb, C.C. A study of storage tank accidents. J. Loss Prev. Process. Ind. 2006, 19, 51-59. [CrossRef]

23. Kadri, F.; Chatelet, E.; Lallement, P. The assessment of risk caused by fire and explosion in chemical process industry: A domino effect-based study. J. Risk Anal. Crisis Response 2013, 3, 66-76. [CrossRef]

24. Abdolhamidzadeh, B.; Abbasi, T.; Rashtchian, D.; Abbas, S.A. Domino effect in process-industry accidents-An inventory of past events and identification of some patterns. J. Loss Prev. Process. Ind. 2011, 24, 575-593. [CrossRef]

25. Khoury, G.A. Effect of fire on concrete and concrete structures. Prog. Struct. Engng. Mater. 2000, 2, 429-447. [CrossRef]

26. Crocker, W.P.; Napier, D.H. Thermal Radiation Hazards of Liquid Pool Fires and Tank Fires. I. Chem. E. Symp. Ser. 1986, 97, 159-182.

27. Hightower, M.; Gritzo, L.; Luketa-Hanlin, A.; Covan, J.; Tieszen, S.; Wellman, W.; Irwin, M.; Kaneshige, M.J.; Melof, B.; Morrow, C.; et al. Guidance on Risk and Safety Implications of a Large Liqufied Natural Gas (LNG) Spill Over Water. In Sandia National Laboratories Report; Department of Energy's Nuclear Security Administration: Albuquerque, NM, USA, 2004. [CrossRef]

28. Cozzani, V.; Gubinelli, G.; Salzano, E. Escalation thresholds in the assessment of domino accidental events. J. Haz. Mat. A 2006, 129, 1-21. [CrossRef] [PubMed]

29. De-Chingi, H.; Shen-Wen, C.; Chien-Hung, L.; Po-Ta, H.; Yi-Ting, S.; Huei-Ru, S. A Study for the evacuation of hospital on fire during construction. Procedia Eng. 2011, 11, 139-146. [CrossRef]

30. Shastri, B.A.; Raghov, Y.S.; Sahadev, R.; Yadov, B.P. Analysis of fire protection facilities in hospital buildings. Adv. Fire Process. Saf. 2018, 183-190. [CrossRef]

31. Nadzim, N.; Taib, M. Appraisal of fine safety management systems at educational buildings. In Proceedings of the SHS Web of Conferences 11, Paris, France, 9 September 2014. [CrossRef]

32. El-Harbawi, M.; Al-Mubaddel, F. Risk of fire and explotion in electrical substations due to the formation of flammable mixtures. Sci. Rep. 2020, 10, 6295. [CrossRef]

33. Shariff, A.M.; Wahab, N.A.; Rusli, R. Assessing the hazards from a BLEVE and minimizing its impacts using the inherent safety concept. J. Loss Prev. Process. Ind. 2016, 41, 303-314. [CrossRef] 
34. Rajabi, F.; Molaeifar, H.; Jahangiri, M.; Taheri, S.; Banaee, S.; Farhadi, P. Occupational stressors among firefighters: Application of multi-criteria decision making (MCDM) Techniques. Heliyon 2020, 6, e03820. [CrossRef]

35. Pu, H.; Luo, K.; Zhang, S. Risk assessment model for different foodstuff drying methods via AHP-FCE method: A case study of "coal-burning" fluorosis area of Yunan and Guizhou Province, China. Food Chem. 2018, 263, 74-80. [CrossRef] [PubMed]

36. Gigovic, L.; Jakovljevic, G.; Sekulovic, D.; Regodic, M. GIS multi-criteria analysis for identifiying and mapping forest fire hazard: Nevesinje, Bosnia and Herzegovina. Teh. Vjesn. 2018, 25, 891-897. [CrossRef]

37. Hassanain, M.A.; Abdul Hafeez, M.; Sanni-Anibire, M.O. A ranking system for fire safety performance of student housing facilities. Saf. Sci. 2017, 92, 116-127. [CrossRef]

38. Van Hoang, T.; Chou, T.Y.; Fang, Y.M.; Nguyen, N.T.; Nyguen, Q.H.; Canh, P.X.; Toan, D.N.B.; Nyguen, X.L.; Meadows, M.E Mapping forest fire risk and development of early warning system for NW Vietnam using AHP and MCA/GIS methods. Appl. Sci. 2020, 10, 4348. [CrossRef]

39. Nyimbili, P.H.; Erden, T. A Hybrid Approach Integrating Entropy-AHP and GIS for Suitability Assessment of Urban Emergency Facilities. ISPRS Int. J. Geo-Inf. 2020, 9, 419. [CrossRef]

40. Saaty, T.L. The Analytic Hierarchy Process: Planning, Setting Priorities, Resource Allocation; McGraw-Hill: New York, NY, USA, 1980.

41. Yazdani, A.A.; Moghaddam, R.T. Integration of the fish bone diagram, brainstorming, and AHP method for problem solving and decision making-a case study. Int. J. Adv. Manuf. Technol. 2012, 63, 651-657. [CrossRef]

42. Harrington, S.; Teitelman, J.; Rummel, E.; Morse, B.; Chen, P.; Eisentraut, D.; McDonough, D. Validating Google Earth Pro as a Scientific Utility for Use in Accident Reconstruction. SAE Int. J. Transp. Saf. 2017, 5, 135-166. [CrossRef]

43. Childs, C. Interpolating Surfaces in ArcGIS Spatial Analyst, ESRI Education Services. 2004. Available online: www.esri.com (accessed on 26 January 2021).

44. Di Piazza, A.; Conti, F.L.; Viola, F.; Eccel, E.; Noto, L.V. Comparative Analysis of Spatial Interpolation Methods in the Mediterranean Area: Application to Temperature in Sicily. Water 2015, 7, 1866-1888. [CrossRef] 